\title{
Urban freight consultations in the Paris region
}

\author{
Laetitia Dablanc • Diana Diziain • Hervé Levifve
}

Received: 26 October 2010 / Accepted: 8 March 2011 / Published online: 13 May 2011

(C) The Author(s) 2011. This article is published with open access at Springerlink.com

\begin{abstract}
Purpose This article describes recent freight consultations in the Paris region (called the Ile de France) and assesses their usefulness to the urban freight policy. The Ile de France is one of 22 French regions, and is one of the largest and most developed metropolitan areas in Europe. It is currently confronting major economic, environmental, and institutional challenges. In this changing context, freight and logistics activities have been acknowledged as major contributors to the region's economic well being that nonetheless have negative environmental effects such as noise, air pollution, and $\mathrm{CO}_{2}$ emissions. To manage freight transport in a more sustainable manner, the City of Paris and, more recently, the Ile-de-France Region,have engaged in consultations with freight transport firms, carriers' organizations, and shippers' associations.

Method Our method is based on personal knowledge and experience, on a quantitative analysis of meeting records, and on interviews with local practitioners and elected
\end{abstract}

L. Dablanc $(\bowtie)$

IFSTTAR (French Institute of Science and Technology for

Transport, Development and Networks),

Noisy-le-Grand cedex, France

e-mail: laetitia.dablanc@ifsttar.fr

D. Diziain

Ile-de-France Region,

33 rue Barbet de Jouy,

75007 Paris, France

H. Levifve

Atelier parisien d'urbanisme (Paris Planning Agency),

17 boulevard Morland,

75004 Paris, France officials. We examine consultations at three levels in the Ile de France Region's institutional framework: the local level, represented by the "neighbourhood councils" in the city of Paris's individual districts; the municipal level, with the Paris Delivery Charter experience (2006-2009); and the regional level, through the Ile-de-France Regional Council's recent experiences with freight consultation.

Results and conclusion We analyse the difficulties encountered when conducting negotiations with the freight and logistics sectors in a complex urban environment. We describe the relationships between local and regional processes, showing how they have benefited from and sometimes overlapped with one another. Conditions for success are suggested, and a few guidelines are proposed.The Paris case leads to three conclusions. First of all, with regard to freight issues, specific consultations need to be implemented, because regular consultationsneglect freight transport issues. Secondly, freight consultations are of little use at the local and municipal levels. They need to be combined with metropolitan or region-wide consultation, because freight movement in urban areas is logistically connected to regional and national supply chains. Finally, it is important that consultation outcomes translate into effective changes in policies and behaviours. If not, well-intentioned freight companies willing to improve their urban operations will be discouraged from doing so and the very purpose of freight consultations, which is to promote more efficient and sustainable urban supply chains based on voluntary commitments, will be lost.

Keywords Urban freight · City logistics · Consultation processes · Participation · Stakeholders' involvement · Public private partnerships $\cdot$ Paris $\cdot$ Freight transport policy 


\section{Introduction: What is at stake when local governments address freight?}

This article describes recent freight consultations in the Ile de France Region and assesses their usefulness to an urban freight policy. Our method is based on personal knowledge and experience, on interviews with local practitioners and elected officials, and on a complete and quantitative analysis of the minutes of neighbourhood council meetings. We examine consultation processes at three levels in the Ile de France's institutional framework: the local level, with the city's "neighbourhood councils" in Paris's 20 districts; the municipal level, with the Paris Freight Charter experience (2006-2009); and the regional level, through the Regional Council's recent experience with freight consultation. We then evaluate the relationships among these three participatory processes, and we identify their usefulness to Paris and to the Ile de France's urban freight policies.

1.1 Freight transport and logistics innovations in the Ile de France Region

The Ile-de-France Region is one of 22 French regions. It is one of the largest and most developed metropolitan areas in Europe. Every day, more than one million deliveries and pick-ups ${ }^{1}$ are made in Ile-de-France to meet the needs of its 700,000 businesses, 5.5 million jobs and 11.8 million inhabitants, as well as its 17 million $\mathrm{m}^{2}$ of warehouses and distribution centres [15]. More than one third of these deliveries $^{2}$ occur in the city of Paris itself, which is at the heart of the metropolitan area (Map 1).

The city of Paris is just one of 1,281 local municipalities that make up the Ile-de-France Region. However, its $105 \mathrm{~km}^{2}$ hold a population of more than 2.2 million inhabitants and contain 1.6 million jobs. It is composed of 20 arrondissements (districts), which are each divided into four quartiers (neighbourhoods).

This rather complicated institutional situation does not prevent the Ile-de-France Region from being a thriving place for logistics activities, making up more than a quarter of France's total square metres of warehouses and logistics centres [15]. This illustrates a fundamental fact about goods movements in cities: it is the economic structure of a city that determines freight movements, much more than the institutional patterns or local policies [8]. Each of the (very

\footnotetext{
$\overline{1}$ This figure is from our own calculations based on the results of surveys made in other large French cities [23]. Routhier et al. [23] have established ratios of the number of urban freight pick-ups and deliveries according to each business category. A major survey and urban freight data collection are currently underway (spring 2011) in the Ile de France region but results will not be available before 2012 . ${ }^{2}$ Same remark as above.
}

numerous) economic sectors present in a large metropolitan area such as the Ile de France Region has its own logistics characteristics [23]. These characteristics in turn determine the types of vehicles and delivery frequencies that each sector needs. Before being delivered to (or sent out of) an urban area, a product will very likely pass through a warehouse, a parcel carrier terminal, or an intermodal yard, in short, a network node where goods will be transferred from one vehicle to another and are often stored, processed, or repackaged. ${ }^{3}$ Thus, a vast band of logistics facilities surrounds cities, especially the largest ones.

One significant result of this organization is that transport chains' urban segment is taken care of by local carriers, which are often very small businesses with low profit margins. To reduce costs, these local carriers use old vehicles that emit large amounts of pollutants. Another result is that the urban goods transport sector remains relatively under-optimized. A sizable part of urban freight transport is inefficient, i.e. it uses more vehicle-kilometres than necessary to supply households and businesses. The freight industry has had to be very flexible in responding to the demands of the new urban economy: decreased size of inventories (zero stock), growing demand for express and urgent deliveries, fragmentation of shipments (a few parcels received each day instead of a consolidated load once a week), fast increase of home deliveries following the rapid growth of on-line shopping. Transport companies managed to fulfil these new demands efficiently but at a high price: poor load factors of the trucks, long working hours, low compliance of local traffic and parking laws.

Thus, the trucks that serve Paris and the Ile de France Region contribute significantly to congestion (15-20\% of vehicles) and pollution. As shown on Table 1 below, nearly $60 \%$ of particle emissions, $38 \%$ of NOx as well as $26 \%$ of greenhouse gas emissions related to transport come from trucks. Noise also represents a severe environmental impact of freight transportation in cities. There are no data for Paris but studies on other French cities showed that during the morning rush hour, the circulation of freight transport vehicles added five decibels $(\mathrm{dB}(\mathrm{A}))$ to the noise from the circulation of private cars (LET et al. [18]).

Large cities can also be places of logistics innovations providing services that are both efficient and more environmentally sound. E-commerce related transport services have been one of the most visible sources of such innovations. Ecommerce now accounts for about $5 \%$ of retail turnover in

\footnotetext{
${ }^{3}$ French shippers' surveys have shown that between 1998 and 2004, the proportion of goods passing through a logistics terminal rose from $66 \%$ to $85 \%$ for shipments leaving the Ile de France region, and from $50 \%$ to $62 \%$ for incoming shipments [11].
} 


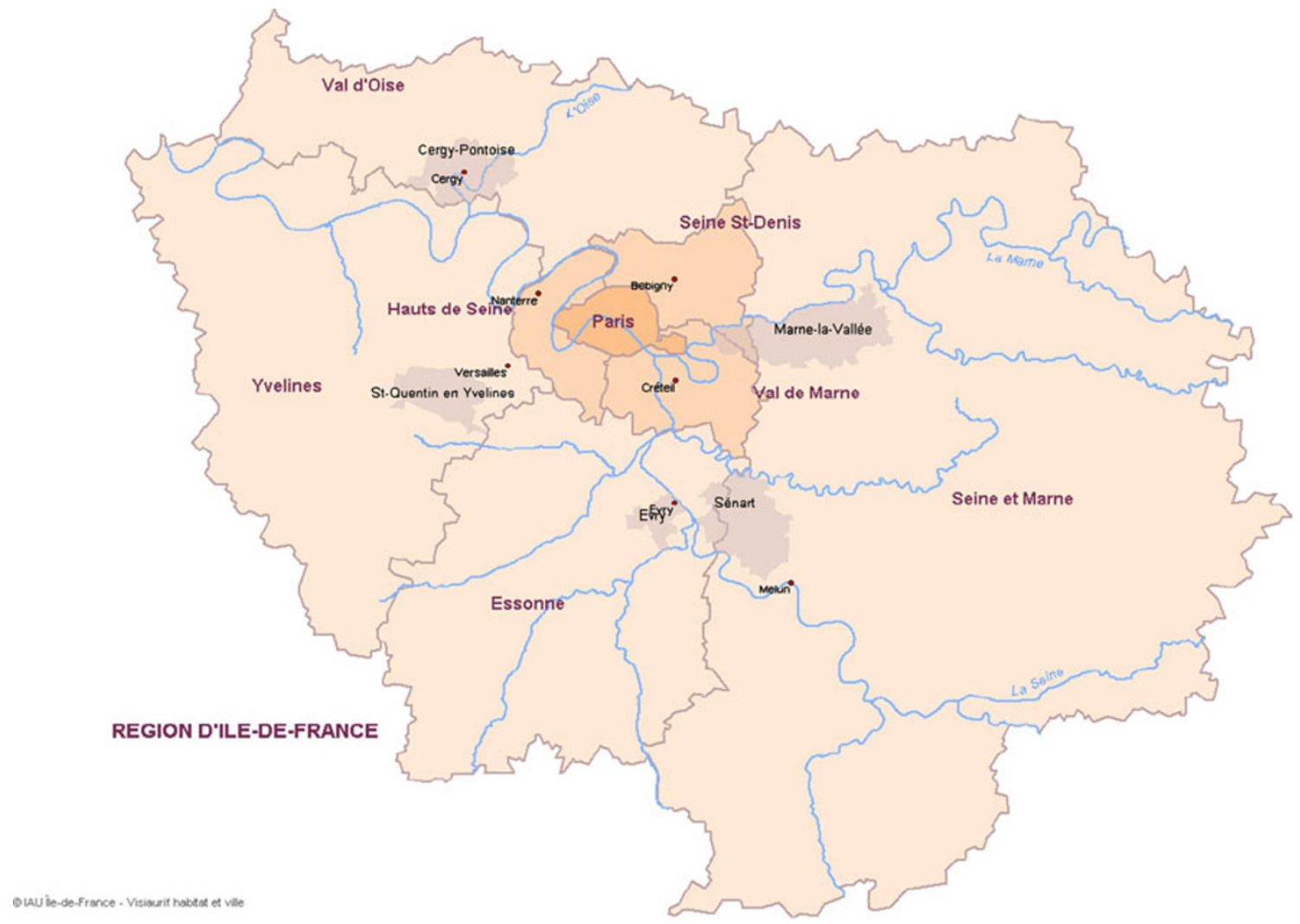

Map 1 Paris and the Ile-de-France Region

Europe, ${ }^{4}$ and the innovations related to this new kind of consumption are concentrated in urbanized areas such as Paris. Star's Services is one of the most innovative French transport firms to appear in recent years. It provides home delivery of grocery products, a market that is considered particularly difficult. The company was created and has seen its growth in the Ile de France Region, which is home to most of its 1,200 vehicles, all of which are refrigerated and have onboard computer systems. The French postal service's new automated package pick-up network originated in Paris, and most of the expansion has been there. A large number of logistics start-ups, such as La Petite Reine, Urban Cab, and BeCycle (all operating electrically assisted cargo tricycles) or Colizen (specializing in customized home delivery of high value-added on-line purchases with small electric vans) are currently conducting experiments in Paris. Some of them work for major industry leaders such as DHL (La Petite Reine), TNT (Green Logistics) and FedEx (Urban Cab).

\subsection{Urban freight policies}

As stated above, urban environments are full of freightderived pollution, congestion, and greenhouse gas emis-

\footnotetext{
${ }^{4}$ Center for Retail Research (www.retailresearch.org/onlineretailing. php, last accessed on 20 January 2011.
}

sions, but are also conducive to innovation in this area. Faced with these contrasting economic and environmental realities, Europe's major cities have tried to design policies that target freight transport. Local freight policies in European cities have always been based on a combination of environmental protection and the imperatives of economic development [7]. The objective of maintaining thriving city centres has often been employed to argue against stricter laws targeting noisy and intrusive delivery vehicles. On the other hand, many trucking activities or industrial activities such as wholesale, textile or warehousing have been expelled from cities because of the traffic they generated. These somewhat "chaotic" [27] and conflicting policies parallel quite important policy shifts overtime. Until the 1980 s, cities primarily or exclusively used municipal ordinances to regulate and restrict freight movements [9]. They responded to general concerns about congestion, street

Table 1 Percentage of trucks' emissions in total transport related emissions in Ile de France

\begin{tabular}{lcccc}
\hline & $\mathrm{CO}_{2}$ & $\mathrm{SO}_{2}$ & $\mathrm{NOx}$ & $\mathrm{PM}_{10}$ \\
\hline Trucks & $26 \%$ & $43 \%$ & $38 \%$ & $59 \%$ \\
\hline
\end{tabular}

LET et al. [18] 
use conflicts, road maintenance and noise. Starting in the 1980 s, more focused environmental concerns led to experimental urban logistics practices, in which cities tried to go beyond traditional command-and-control regulatory policies. For example, they financed the testing of low-pollution delivery vehicles and the creation of centralised urban freight consolidation and distribution [5]. These experiments mostly concerned northern European cities, Germany and a few French cities, and more recently Italian cities [28]. In the mid 1990's, economic concerns led to a progressive retraction of these municipal initiatives. Cities have been increasingly reluctant to pay subsidies covering the extra costs generated by the operation of urban consolidation terminals. Many municipalities have thus turned towards the promotion of new regulations based on environmental standards, including zones which prohibit access to old commercial vehicles [1, $2,6,7,28]$. More audacious policies such as automated enforcement or congestion pricing $[17,20]$ as well as the promotion of innovative equipment and vehicles, or waterways and rail transport $[14,19,26]$ are becoming increasingly popular.

In France, one way that cities prefer to become involved in urban freight transport management is through consultations that bring together public decision-makers with transport and other business stakeholders. Other countries have led the way, most notably the United Kingdom and the Netherlands. U.K. cities have had a long tradition of 'Freight Quality Partnerships' $[13,24]$. In the Netherlands, a dedicated national forum for urban freight (the Sustainable Mobility Platform) has promoted regular meetings and discussions with freight and business stakeholders. Since 1996, France's Domestic Transport Orientation Law (LOTI), ${ }^{5}$ (in its Article 28-1) has strongly encouraged cities to adopt such procedures. The city of Paris has been particularly involved in freight transport consultation since 2001, as has the Ile-de-France Region since 2008. We will describe these experiences in detail, focusing on the unique aspects, as well as outcomes and challenges, at each administrative level, Section 2 addresses consultation at the Paris local neighbourhood level. Section 3 examines issues surrounding freight consultation at Paris's municipal level, and Section 4 deals with the regional council level. Section 5, as a conclusion, provides an analysis on the relevance of freight consultations for an urban freight policy and on the transferability of the Paris experience.

\footnotetext{
$\overline{5}$ Article $28-1$ of the LOTI calls upon all major French urban areas, when drawing up their Urban Travel Plans (plans de déplacements urbains, or PDUs). to "manage freight transport and delivery, while rationalising metropolitan supply conditions and supporting commercial and artisanal activities."
}

\section{The neighbourhood council: not a relevant place to discuss freight transport issues}

The 80 Paris neighbourhood councils (conseils de quartier) are local, non-decision-making bodies whose randomly selected or appointed members meet two or three times per year. Neighbourhood councils were created in the early 2000s as part of a set of new policies aimed at increasing bottom-up decision-making and local community involvement in Paris's municipal government. As places where local consultation actively occurs, these councils form the basis for most of the municipality's consultation processes and are a good place to begin our evaluation.

We have analyzed the importance given to freight and delivery issues at a total of 40 meetings held in the fifteentharrondissementduring 2005 and 2006. The fifteenth arrondissementis located in southwest Paris. We selected it for study because, as one of the largest arrondissementsof Paris, it has been the recipient of many local transport and urban projects (such as the introduction of bike lanes). Also, its leaders have been particularly active in promoting neighbourhood council meetings, which they view as a tool for having their voices heard (the fifteenth arrondissement is currently politically opposed to the Paris Mayor), and the meetings have always been very well attended. We specifically focused on the relative importance of freight compared with other issues, as well as the types of stakeholders involved. We used a lexical search and made a detailed analysis of the meetings' minutes. We found 28 references to freight and deliveries, i.e. an average of 0.7 references per meeting. Compared with other transport and public space related issues discussed during the meetings, for which there were often 2 to 3 references per meeting,the number of references to freight was particularly small. (Examples of other issues raised were: car parking; bike lanes; pedestrian crossings; and location of bus stops) [12]. This means that these problems receive very little attention from neighbourhood councils, except when goods transport is central to the issue discussed (such as the reorganisation of lorry access to the Porte de Versailles Exhibition Park).

When freight issues were discussed, the specific themes were the following (Fig. 1):

The main theme discussed related to the difficulty of accessing shops for delivery, particularly when new cycle lanes were introduced. Impacts of deliveries were the second most mentioned topic. The effects of deliveries cited by council members in order of frequency, were congestion, safety, and noise. There was only one reference to air quality problems. Local effects were also discussed, such as the manoeuvres that trucks must perform to reach a supermarket on a narrow street. These local issues were surprisingly few. Apart from a single discussion concerning the future of an abandoned railway encircling Paris (the petite ceinture) and a debate on the future 


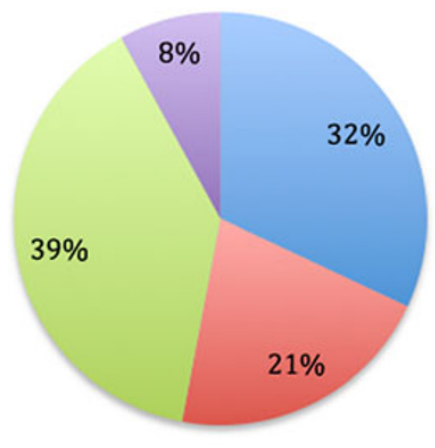

- Impacts and pollution by freight activities

Conflicts of street use generated by freight activities

Accessibility to loading/unloading facilities

Multimodality, clean and experimental vehicles

Fig. 1 Distribution of freight-related thematic expressions in neighbourhood council meetings. Source: L. Dablanc. $100 \%=28$ freightrelated references

of river ports, the delivery-related themes were short-term issues unrelated to the challenges of innovation (clean vehicles, for example). Only one goods transport reference concerned the general organization of deliveries in Paris.

Nearly half (46\%) of the references involved opposition to or a negative view of freight operations, presenting them as noisy, dangerous, and cumbersome. However, the other half $(54 \%)$ presented freight activities in a positive light, stressing the necessity for delivery bays and the need to improve lorry drivers' working conditions. Most participants in the meetings agreed that the redesign of and "traffic calming" on rue du Commerce (a very busy street with many stores) shouldallocate more space to on-street delivery at the expense of car parking. On the whole, the perception of freight issues by participants in neighbourhood councils was not as negative as we initially expected.

The 28 references to goods transport in the debates were composed of 78 individual contributions. Figure 2 provides a breakdown of these contributions by category of participant:

Over one-third of contributions were from residents, and chiefly concerned perceived noise, pollution, and greenhouse gas emissions. A non-negligible number of contributions also concerned the necessity of commercial delivery access (plumbers, tradesmen).

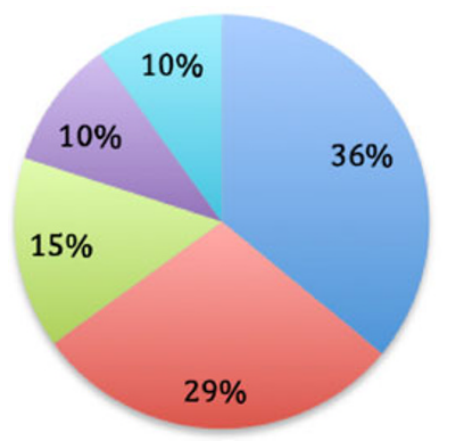

\section{Eesidents}

$=$ Elected
representatives
Experts

= City's technical staff

= Citizens' groups

Fig. 2 Origin of contributions during neighbourhood council's debates concerning deliveries. Source: L. Dablanc. $100 \%=78$ freight-related contributions

Contributions from citizens' groups (parents of schoolchildren, property owners' associations, or residents' associations) were rare at approximately $10 \%$. We note that businesspeople and their representative associations (including delivery companies) were rarely present at these meetings. The only meeting that attracted a business representative concerned the rue du Commerce redesign. This representative was present mainly to explain the project to the other participants, who were mostly residents. Apparently,other meetings concerning the rue du Commerce redesign, outside the neighbourhood council context, were taking place involving retailers' associations and storekeepers.

The arrondissement'scouncil representatives made up $29 \%$ of the goods transport and delivery-related contributions. In general their contributionswere well-informed. Some used delivery and store access problems to challenge entire redevelopment projects (e.g. the BirHakeim - Montparnasse bicycle path). They intervened in differing ways depending on whether they were acting as representatives of the arrondissement (as opposed to the Paris City Council, for example), as sponsors of a local project that they wished to defend, or as chairmen/coordinators of a neighbourhood council (in which case they attempted to launch debate).

Street engineers and other invited outside experts accounted for a quarter of contributions. They attempted to explain the constraints and realities of delivery activities in layman's terms and promised technical solutions. Technical knowledge of the challenges and planning issues concerning deliveries was previously in short supply, but this survey showed it has taken on a greater importance in Paris's municipal administration.

On the vast majority of issues, Paris neighbourhood councils are an important basis for consultation. In the case of freight transport, however, they have proven to be of little use. Freight and logistics issues are not really discussed in these councils because direct stakeholders such as transport companies and shippers are not active participants. However, when freight and logistics are discussed in local councils, it is in a rather cooperative way, e.g. not only focusing on negative impacts but also stressing theneed for better access to loading/ unloading areas.

\section{The proactive implementation of a freight consultation policy in Paris in the early 2000s}

In France, the city of Paris stands out in that awareness of freight mobility's importance grew beginning in the early 2000s. As a result of innovations in passenger mobility, public authorities began to consider the necessity of a general freight mobility program. The street redesign undertaken in 2001 which created bus lanes made deliveries very difficult in some Parisian streets, and led to conflicts with truck companies and 
shippers. The parties involved were able to overcome this contentious situation by creating an environment for consultation and discussion between public and private entities.

The consultation begun in 2002 brought together the Mayor and the Deputy Mayor in charge of transport with freight transport stakeholders: those who generate flows (represented by chambers of commerce and shippers' associations), transport company federations, rail and river infrastructure managers, energy providers, and other institutions (including national and regional government and environmental agency representatives). Several key political party and private players, including public and business representatives, stated that they wanted freight mobility to have equal consideration with other transport activities, thus allowing innovative and ambitious policies to be implemented.

The following objectives were set:

- Reducing negative environmental effects of freight and deliveries.

- Reserving space for freight activities within urban areas.

- Improving working conditions for goods delivery personnel.

- Relocating logistics facilities within the city.

- Increasing the attractiveness of the city of Paris.

An action plan and a pilot committee were created, and three working groups were launched simultaneously. The first sought to collect information about the delivery sector. Studies, surveys, and diagnostics were carried out to better document and understand how this industry functioned on a daily basis. The second group's objective was to make the city's logistics activities more efficient. Action was taken through regulations and real estate (both on public and private land), with several exemplary experiments emerging. The third group developed prospective analyses for the medium and long term, and focused on innovative urban logistics and organisational techniques.

In June of 2006, the participants agreed to sign a Freight Charter. ${ }^{6}$ This agreement was active for a 3 year period and was not legally binding. It was based on the notion of commitment and "win-win" principles. In addition, a charter follow-up committee was created to assess the signatory parties' compliance. This committee was also set up to resolve problems and conflicts concerning goods deliveries within Paris.

The partners agreed to redefine the city of Paris's regulations, acting in the following three areas:

- Deliveries regulation.An "environmental" regulation was introduced for the first time in Paris, reserving

\footnotetext{
${ }^{6}$ The Freight Charter can be downloaded from the city of Paris' website at: www.paris.fr/portail/deplacements/Portal.lut? page_id $=376 \&$ document_type_id $=5 \&$ document_id $=25945 \&$ portlet_ $\mathrm{id}=1187$ (last accessed on 12 January 2011).
}

17:00 to 22:00 for the least polluting delivery vehicles. Here, "least polluting" was defined as meeting the most recent European Union standards for the manufacturing of gas or electric trucks. ${ }^{7}$

- The provision of on-street delivery areas. Street space was redesigned to better accommodate on-street delivery areas, and new rules were created for their use. The dimensions for these delivery areas were modulated based on the type and quantity of stores along the street, and by the stores' needs. Home delivery areas every $100 \mathrm{~m}$ were also incorporated into residential streets. Discussion on the use of delivery areas began because, more than half the time, these areas were used for illegal parking. French traffic laws allow any vehicle to use delivery bays, but for loading and unloading only. Traffic enforcement personnel have no way of knowing whether or not a loading/unloading operation is under way. To eliminate this ambiguity, partners agreed to limit the use of delivery areas to 30 minutes. This limit is enforced with a 'parking disc'. This is a time setter that lorry drivers must use to identify the time of their arrival. Over 100,000 of these were manufactured by the city and distributed by freight organizations to their members. A 2008 survey showed that the new strategy resulted in a better availability of delivery bays during the day. Long term parking on the bays decreased. Enforcement has increased considerably, with $13 \%$ of illegal stops fined in 2008 versus only $1 \%$ in 2004 .

- Planning and zoning regulations. Several freightspecific items were added to the municipal land use master plan, which is called the "plan local d'urbanisme", or PLU, in French. The first concerns the freight delivery parking area set-aside requirements when constructing new commercial buildings over $500 \mathrm{~m}^{2}$, new hotels with over 150 rooms, or new offices over 2,500 $\mathrm{m}^{2}$. The second aims to preserve rail and waterway transport sites within Paris, and to accommodate their logistic activities. Historically, Paris developed around industrial and logistics sites, particularly the Seine River, rail yards, and canals. Many of these sites have now become housing developments or green spaces, or are being used for public amenities. The few that remain have fallen into disuse and are not up to minimum operational standards. Thus, logistics firms have continued to leave the urban centre, moving to the inner, then the outer suburbs. Due to increasing

\footnotetext{
${ }^{7}$ Details are available at: http://www.paris.fr/portail/deplacements/ Portal.lut?page_id=376. Last accessed on 12 January 2011. The former truck access regulation in Paris was exclusively based on the dimension (expressed in square metres) of a truck. Different dimensions were given different delivery time Windows, creating a complex set of rules.
} 
distances between warehouses and delivery points within urban areas, truck-kms in the Ile-de-France Region have increased along with the associated external effects: energy consumption, pollution, noise, greenhouse gas emissions, and consumption of available space [10]. In order to reserve urban logistics spaces in the Paris PLU, it was necessary to make political trade-offs and strike a balance between these spaces and other developments such as housing and office space. The Paris PLU now includes these logistics sites in "Major Urban Service Zones" which are dedicated to public amenities. Thirteen shared transloading sites were also designated along the Seine, on a strip between the Bercy and Grenelle bridges. These facilities can be used at certain times to transfer goods between boats and delivery vehicles, but are available for other uses at other times.

In October 2009, the City and its partners assessed their 3 years of cooperation under the Freight Charter. The most salient conclusions were the following:

- The importance of dialog. The first advantage of consultation is to bring together groups who do not normally meet. This helps develop an understanding of each stakeholder's specific limits, needs, and difficulties, and defuses conflicts before they break out.

- A time mismatch between actions by public and private parties. In general, public authorities and the private sector do not function on the same time frame. The private sector is accustomed to setting plans into motion rapidly and tends to find public decisionmaking processes very slow. On the other hand, private sector investments are geared toward the long term because of amortization concerns. The private sector seeks to coordinate these investments with future regulatory changes.

- Inadequate enforcement of traffic and parking regulations. This is a general and long-standing problem in Paris, and is even more acute for truck and delivery regulations. Enforcement personnel have not been trained on freight regulations and do not know much about them. Furthermore, the institutional organization of Paris dissociates local regulatory power (the municipality) from enforcement (the national government), and the means dedicated to enforcement are currently insufficient. Private businesses demand better enforcement, as this is the only way to distinguish "virtuous" transport companies from their less scrupulous competitors.

- The necessity of strengthening land use strategies. The city of Paris is trying to conserve and develop logistics sites within its territory through its PLU (master plan), but land scarcity is also an issue in the inner suburbs.
All participants agree that it is necessary to reflect on and facilitate actions at a scale beyond that of the city of Paris.

- Inadequate representation. The question arose as to whether the freight organizations participating in the consultation were sufficiently representative. There is very little communication between a delivery driver who works daily in the field and his/her representative who participates in institutional discussions. In addition, large professional federations and carriers are overrepresented relative to businesses with only a few employees.

- The usefulness of experimentation. New forms of urban logistics organisation became more visible through innovative experiments. All the experiments promoted by the city of Paris have been widely advertised in the specialised as well as the local press. Events and conferences have been organised with stakeholders presenting the new logistics principles and results. Though these experiments concern only an anecdotal fraction of urban freight flows, they are effective in communicating possibilities and spreading ideas that promote changes in behaviour.

- The relevant territory is larger than the city of Paris. The Paris consultation created an institutional framework for public-private discussion. It gradually became evident that the problems seen in Paris also existed in the suburbs. The organisation of freight flows is primarily regional, with warehouses that serve the entire region. When faced with the difficulty of supplying Paris, businesses adopt strategies that impact the surrounding municipalities. Beyond the specifically urban problems typical of Paris and the dense neighbouring municipalities, others exist that can be dealt with only at a larger scale, by the Ile-de-France Regional Council.

\section{A new participant in freight consultation since 2008: the Ile-de-France Regional Council}

The Ile de France Region has no legal responsibilities regarding freight transport. Its policy of supporting infrastructure development is based on the general responsibility for territorial development it received in the 1982 decentralisation laws. Like all French Regions, it co-finances infrastructures under "project contracts" with the national government. We are currently in the fifth generation of these contracts, and since 2000 they have included a section on goods delivery covering rail and waterway infrastructure financing. Between 2000 and 2010, the annual regional budget for freight rose from 6 million to 35 million euros. 
Regional investment in freight beyond financial support for infrastructure was a result of several factors:

- Organisational: the creation of the Ile-de-France Transport Syndicate (STIF, the transport authority for passenger transport), in which the Region has held the majority of seats since 2006, led to interest in new transport issues, principally freight.

- Human: The new transport director was convinced that action on freight transport was necessary, in addition to infrastructure investment.

- External: A 2007 exploratory study [25] carried out in preparation for the Ile-de-France Regional Master Plan revealed strong expectations from institutional and private entities.

- Awareness of elected officials: An evaluation of the 2000 regional urban transport plan (plan de déplacementsurbainsd'Ile-de-France, or PDUIF) in 2007 revealed that its freight-oriented actions had been weakly implemented, and the elected official in charge of transport decided to act. The personal involvement of another official who was also a member of the Ilede-France public land holdings establishment also greatly contributed to discussions on land and on logistics real estate.

To design a new policy that was more favourable to freight, the Region sought to expand its expertise. It carried out its own studies and co-financed others with partners. It financed a major survey and data collection which started in 2010, and did origin-destination counts and surveys at major multimodal nodes. However, above all, it launched consultations with freight transport and logistics professionals.

The 2007 study cited above [25] consisted of about 20 interviews with private and public entities. The final report submitted in 2008 [22] covered several topics, including necessary public actions: to organize and plan the development of major logistics facilities, to propose a regional harmonisation of local rules for urban deliveries, to supply appropriate infrastructure in a context where passenger transport needs always come first, and where both capacity needs and the technical details of freight transport are neglected, to limit freight-caused noise, pollution, greenhouse gas emissions, and congestion.

The Region also found that it had become necessary to elevate freight and logistics policies to the regional level. Sub-regional entities such as municipalities and départementswere too small to be visible enough, and their limited transport responsibilities kept them from being able to implement the necessary multimodal responses.

Finally, the 2007 study identified the tools needed by the Region to implement these policies. The various plans available (regional urban transport plan, master plan, air quality plan; project contracts, household waste management plan) were deemed quite sufficient to convey the Region's point of view and the strategies defined in working groups into instructive or even legally binding texts.

This exploratory study concluded with plans to launch a true regional consultation procedure with transport and logistics professionals, in order to develop a formal regional policy on goods transport. This consultation was carried out from April to December 2009, and included the following four workshops:

- Employment and professional training

- City logistics

- Major terminals and infrastructures

- Logistics real estate and developments

The consultation concerned regional-scale freight problems as well as intra-urban goods transport. Each consultation workshop met three times. Problems and issues were discussed in the first meeting. The second concerned operational solutions and tools. Protocols and concrete actions such as written partnerships and follow-up tools were worked out at the third meeting.

This consultation was not intended to be comprehensive, but to focus on issues that were of direct concern to the Region, at a scale small enough to make concrete solutions plausible, but large enough to be of truly regional interest.

An extranet site dedicated to logistics and freight transport consultation in Ile-de-France was created to complement the workshops. It provided information on the master plan and project contracts, as well as various studies by the regional planning and development institute. The site also provided contact information for participants, minutes, and presentations for each workshop. This site was made permanent, and today (early 2011) it offers information about the Region's work to consultation participants and other institutional partners.

The consultation phase ended with a closing seminar, attended by all participants and by people external to the process, which allowed the groups to share their conclusions. The regional vice president in charge of transport provided political guidance. Seven elected officials from the majority participated, including the president of the Regional Transport Commission and the elected official in charge of urban transport plans. Recognized experts helped direct working group activities and assisted in writing the final report. Two or three meetings were held on each theme, resulting in 35 action items.

Two main tools will be used for implementation: the regional urbantransport plan (PDUIF), which is currently being revised; and one or more framework agreements. The first one will be created in 2011, and may contain actions on land use and municipal and some city logistics experiments. 
This consultation procedure helped the Region find its position among public and private stakeholders and target appropriate types of intervention. Three regional-scale concerns were identified:

- Questions surrounding land use, development, and real estate. Here the Region is entirely within its territorial development role and can make use of the regional public land holding agency.

- Support for experiments and exemplary practices.

- Infrastructure investment.

The consultation concluded that using urban planning documents was necessary, and that the regional urban transport plan (PDUIF) would be a relevant tool. The current version of the PDUIF requires that space be reserved for logistics in future developments, and provides a map of protected logistics sites

The Department of Transport was given the mission of implementing strengthened or renewed policy favouring freight movement. Though freight issues span several regional responsibilities (i.e. economic and territorial development, transport, and job training), the conclusions of the consultation primarily concern transport. In the future, the action items will need to be integrated into other regional mechanisms for economic and territorial development and job training, perhaps through contracts with subregional entities.

The consultation was carried out at a difficult time politically: it ended 3 months before France's regional elections (March 2010). Elected officials were focused on passenger transport issues, as this is a politically sensitive topic. The freight action items are now in the process of being set in motion by the new administration.

The consultation defined precise, consensual actions and also managed to involve elected officials in a subject with which they were unfamiliar. It will need to be followed up by another consultation with elected (municipal) officials, who have the power over land use zoning, building permits and traffic regulation and enforcement.

\section{Conclusion}

\subsection{Three different consultation processes}

In this paper, we have examined the participatory activities that are most closely associated with freight transportation issues in the Ile de France Region today: local neighbourhood councils in each Paris district, the Paris-wide freight partnership initiative which resulted in the Paris Freight Charter in 2006, and the regional consultation between the Ile-de-France Region's decision-makers and freight stakeholders which took place in 2009.
Stakeholders participating in these meetings were quite different depending upon the level at which they participated. At the local level, few direct players such as transport companies or their organisations attended the meetings. Freight issues were discussed by indirect stakeholders, such as the city's technical staff and elected representatives. This may not be specific to Paris. Direct interest for urban freight from politicians and municipal staff was also observed for London, according to Browne et al. [4]. The growing participation of local policy-makers in European city networks [26] shows that urban freight is emerging as a new theme for European policy-makers, and a new technical field of expertise for their municipal staff, who are sometimes more acquainted with the economic data and technicalities of urban freight than the transport companies themselves.

At the Paris municipal and regional levels, freight consultations associated many more freight stakeholders than at the local level. Transport companies and their organisations, from groups representing small operators and owner-drivers to groups representing large transport and logistics providers, as well as specialised trades (refrigerated transport, express transport, home deliveries) were present and very active in the discussions. This shows that the stakes were quite high for the industry, which identified freight participatory initiatives as places where actual municipal and regional policies could be formed. The freight companies and organisations who participated in the Paris consultation eagerly participated in the regional consultation too, with additional stakeholders such as the economic development and real estate sectors.

These differences in the levels of participation are also visible in the issues raised and the direct outcomes of each category of meetings. At the local level, freight topics discussed related to the daily life of deliveries, including impacts for the residents and working conditions for the delivery staff. Solutions were not discussed except in some very specific cases such as the rearrangement of the delivery bays in a very busy retail street, or routes and parking areas for the trucks accessing an exhibition hall. At the municipal level, issues examined were both very practical and broad ranging, leading to a reformulation of traffic and parking regulations, land use zoning and a new management of on-street delivery bays. At the regional level, an additional group of stakeholders, the real estate developers, emerged and imposed logistics land use and development as a dominant item on the meetings' agenda. The Region's representatives (elected officials and staff) were willing to endorse this theme as it is part of their general mandate on regional economic development.

Today (2011), many stakeholders believe that the regional level is the most appropriate level to go further and to implement policies that were discussed during the 
consultations. The 2006 Paris Freight Charter had positive outcomes but it lacked enforcement: the "virtuous" truck companies (the companies that use clean vehicles and comply with delivery time windows) do not feel privileged enough compared with the other operators. A regional scale is believed to bring better enforcement and a harmonisation of different municipal truck access regulations. Futhermore, the issue of logistics land has been acknowledged by all as a key challenge for the future of urban freight operations in Paris and Ile de France, and it is better dealt with at a regional level.

The Region, therefore, has come out of these different levels of consultations as the leader for future partnership efforts. It is not known, however, whether the Region will have sufficient legal and political power to implement the measures adopted in the freight meetings. The Region can require a harmonisation of truck access and delivery regulations to all municipalities in its regional transport plan (PDUIF). It can introduce an environmental standard for trucks in both the PDUIF and the regional air quality plan. However, both plans still need to be enforced at municipal levels, and past periods have shown that municipalities would take a very long time in enforcing the regional requirements, if they do it at all [7]. The Region can also determine the general land uses of the regional territory, including logistics land uses, in its regional master plan (SDRIF). But as Gilli and Offner have shown [16], municipal zoning laws have also been very slow in taking into account the requirements of the SDRIF.

\subsection{Are consultations useful for urban freight policies?}

Bickerstaff et al. [3] argue thatpromoting public involvement and participation does not substantially impact local transport policies, because participants'comments are not incorporatedinto local transport plans or other documents. Actual transport policies, then, do not benefitfrompublic involvement.

With regards to freight, wesuggest a different conclusion. If some conditions are met (seebelow), consultations are useful, and a necessary basis for an urbanfreightpolicy. In Paris and Ile de France, there were many positive outcomes resulting from the consultations, and some of them have directly influenced urban freight policies [21], resulting in some interesting developments. Two main successes so far can be identified. (1) The global reorganization of on-street delivery bays has led to more numerous, better protected and better designed delivery bays available to delivery vehicles. (2) Nearly a dozen city logistics experiments have been conducted in Paris, with strong support coming from the Paris Freight Charter's partners. The impacts of these projects are quite significant, although only at the level of each experiment. For example, a new organisation of Chronopost (an express carrier) for its delivery operations in the central districts of Paris has saved diesel powered vehicles $41,000 \mathrm{~km}$ and reduced $\mathrm{CO}_{2}$ emissions by 23 tons per year, a decrease of $60 \%$ compared to the previous situation ${ }^{8}$ [26]. Other propositions or decisions resulting from the freight consultations have not yet resulted in effective policies. These include, for example, the protection of land parcels for logistics activities or the promotion of cleaner vehicles through environmental standards. The obstacles, as we mentioned above, came from the fact that Paris, as a single municipality, was not able to enforce the measures or to deal with regional logistics activities in a coherent way.

The Paris case leads us to identify three conditions that need to be met in order for a participatory approach to provide valuable input to an urban freight policy. We suggest that other cities willing to adopt some of Paris's positive outcomes, and avoid the negative ones, take them into account.

First of all, with regard to freight issues, dedicated consultation processes need to be implemented, targeting freight interest groups and organizations. In Paris, specific freight partnerships have been set up, even though regular consultations with neighbourhood councils already existedin Paris's 80 neighbourhoods. In these neighbourhood councils, officials can discuss municipal affairs with local communities, providing a potential arena to reach out to freight private stakeholders and promote their involvement in the design of a local freight policy.However, it was quickly understood in Paris that regular consultations with the neighbourhood councils are rather useless with regards to freight transport issues. Direct freight stakeholders such as truck companies do not participate in these meetings. Other stakeholders from the private sector such as shopowners participatein many of these meetings but are not interested in delivery issues.

Secondly, freight consultations need to be conducted at a metropolitan and preferably a regional level. Municipal level initiatives such as the Paris Freight Charter need to be combined with metropolitan or region-wide consultation. Because freight movement in urban areas is logistically connected to regional and national supply chains, only a metropolitan or regional level of government can guarantee coherent and effective discussion with freight decision-makers.

Thirdly, in any case, the institution eventually in charge of the consultation will need to have sufficient legal and political leverage to guarantee a certain amount of

\footnotetext{
${ }^{8}$ Two thirds of this positive impact result from the use of electric vehicles, and the remaining reduction in $\mathrm{CO}_{2}$ emissions is due to the decrease in vehicle- $\mathrm{km}$ resulting from the rationalization of the delivery tours due to the use of an urban logistics terminal instead of a suburban one.
} 
enforcement of the measures decided during the consultation meetings. It is very important that consultation outcomes translate into effective changes in the behaviours of both the private and public parties involved in urban freight operations. If not, well-intentioned freight companies willing to improve their urban operations will be discouraged from doing so and the very purpose of freight consultations, which is to promote more efficient and sustainable urban supply chains based on voluntary commitments, will be lost.

Acknowledgements The authors would like to thank the participants of Paris and Ile-de-France freight consultations who provided useful information for our research, and the anonymous reviewers for their helpful comments on an earlier version of this paper.

Open Access This article is distributed under the terms of the Creative Commons Attribution License which permits any use, distribution, and reproduction in any medium, provided the original author(s) and source are credited.

\section{References}

1. Anderson S, Allen J, Browne M (2005) Urban logistics: how can it meet policy makers' sustainability objectives? J Transp Geogr 13(1):71-81

2. Baybars M, Browne M (2004) Developments in urban distribution in London, in Taniguchi, E. \& R. Thompson, Logistics Systems for sustainable cities, Proceedings of the $3 \mathrm{rd}$ International conference on city logistics, Madeira, Portugal

3. Bickerstaff K, Rodney T, Walker G (2002) Transport planning and participation: the rhetoric and realities of public involvement. $\mathrm{J}$ Transp Geogr 10:61-73

4. Browne M, Allen J, Attlassy M (2007) Comparing freight transport strategies and measures in London and Paris. Int $\mathrm{J}$ Logistics Res Appl 10(3):205-219

5. Browne M, Sweet M, Woodburn A, Allen J (2005a) UrbanFreight consolidation centres. Final Report for the Department for Transport, University of Westminster, $\mathrm{p} 185$

6. Browne M, Allen J, Anderson S (2005) Low emission zones: the likely effects on the freight transport sector. Int J Logistics Res Appl 8(4):269-281

7. Dablanc L (2008) Urban goods movement and air quality, policy and regulation issues in European cities. J Environ Law 20 (2):245-266

8. Dablanc L (2007) Goods transport in large European cities: difficult to organize, difficult to modernize. Transp Res A 41:280-285

9. Dablanc L (1998) Le transport des marchandises en ville: une gestion publique entre police et service. Editions Liaisons, Paris, 83

10. Dablanc L, Rakotonarivo D (2010) The impacts of logistic sprawl: how does the location of parcel transport terminals affect the energy efficiency of goods' movements in Paris and what can we do about it? In Tanguchi E, Thompson RG (eds) Procedia - Social and Behavioral Sciences, The Sixth International Conference on City Logistics 2(3): 6087-6096
11. Dablanc L, Routhier JL (2009) La partie urbaine de la chaîne de transport, premiers enseignements tirés de l'enquête ECHO. In Guilbault M (2009) Enquête «ECHO» - Les apports des enquêtes chargeurs pour la connaissance des chaînes de transport de marchandises et de leurs déterminants logistiques, Actes ${ }^{\circ} 121$, Les Collections de l'INRETS, pp 167-174

12. Dablanc L, Gallez C (2008) The perception of street space by the citizens, an analysis of Paris neighbourhood councils' meetings. European Transport Conference, 6-8 October, Noordvijkerhout, The Netherlands

13. Department for Transport (2003) Freight Quality Partnerships Case Studies, Good practice case study 410, p 21

14. Dinwoodie J (2006) Rail freight and sustainableurban distribution: Potential and practice. J Transp Geogr 14(4):309-320

15. DREIF (2009) Approfondissement de l'estimation régional du parc d'entrepôt en Ile-de-France, www.ile-de-france.equipement. gouv.fr/IMG/pdf/Estimation_parcentrepots_DREIF_cle715a47. pdf (last consulted 12 January 2011)

16. Gilli F, Offner JM (2009) Paris, métropole hors les murs: aménager et gouverner un Grand Paris. Presses de Sciences Po, Paris

17. Holguín-Veras J, Wang Q, Xu N, Ozbay K, Cetin M, Polimeni J (2006) The impacts of time of day pricing on the behavior of freight carriers in a congested urban area: implications to road pricing. Transp Res A Policy Pract 40(9):744-766

18. LET - Aria Technologies - Systems Consult (2006) Mise en place d'une méthodologie pour un bilan environnemental physique du transport de marchandises en ville, consommation, émissions, qualité de l'air. ADEME, CERTU co-publishing, Lyon

19. Maes J, Vanelslander T (2010) The use of rail transport as part of the supplychain in an urbanlogisticscontext, presentationat the 12th world Conference on Transport Research, 11-15 July, Lisbon, Portugal

20. Quak H, van Duin J (2010) The influence of road pricing on physical distribution in urban areas. In Tanguchi E, Thompson RG (eds) Procedia - Social and Behavioral Sciences, The Sixth International Conference on City Logistics 2(3): 6141-6153

21. Ripert C (2008) Les marges de manoeuvre des collectivités locales: le cas de la ville de Paris, Presentationat Carrefour $d u$ Predit 3, May 5, Paris

22. Roger-Machart J, Salini P (2008) Rapport de mission sur les transports de marchandises et la logistique en région Ile de France, Region Ile-de-France, p 21

23. Routhier JL, Segalou E, Durand S (2001) Mesurer l'impact du transport de marchandises en ville- le modèle Freturb (version 1), Programme national marchandises en ville, DRAST-ADEME, p 104

24. Scottish Executive (2006) Establishing freight quality partnerships. A guide for regional transport and local authorities. Smarter Scotland, Edinburgh, p 10

25. STIF (2007) Rapport d'évaluation du PDU d'Ile-de-France, Syndicat des Transports d'Ile-de-France \& Région Ile-de-France.

26. SUGAR (2010) Good practices analysis, Deliverable 3.3 (www. sugarlogistics.eu)

27. Van Duin J (2006) Chaos in urbanfreightpolicies? A comparison between Dutch cities, presentationat the National Urban Freight Conference, Long Beach, U.S.A., February 1-3.

28. Ville S, Gonzales-Feliu J, Dablanc L (2010)Investigating the limits of restrictive policies for urban freight transport: the case of Vicenza, Italy. 12th world Conference on Transport Research, 1115 July, Lisbon, Portugal 